\title{
Primary giant synovial sarcoma of the right ankle in a woman living with HIV-AIDS: a rare concurrence
}

\author{
Antonio Jose Reyes, ${ }^{1}$ Wesley Greaves, ${ }^{2}$ Kanterpersad Ramcharan, ${ }^{\circledR 3}$ \\ Fidel Rampersad ${ }^{\oplus}$
}

${ }^{1}$ Medicine, Infectious Disease Unit, San Fernando Teaching Hospital, San Fernando, Trinidad and Tobago

${ }^{2}$ Pathology, San Fernando Teaching Hospital, San Fernando, Trinidad and Tobago ${ }^{3}$ Medicine, Surgi-Med Clinic, San Fernando, Trinidad and Tobago ${ }^{4}$ Radiology, University of the West Indies, St Augustine, Trinidad and Tobago

\section{Correspondence to} Dr Kanterpersad Ramcharan, kramcharan79@yahoo.com

Accepted 5 March 2019

\section{DESCRIPTION}

A 35 -year-old woman living with HIV presented with progressive wasting syndrome and a slowly growing self-neglected right ankle mass for which she refused to seek medical attention and investigations (biopsy and image studies) for 12 months. There was no previous history of cancer, exposure to chemicals carcinogens or radiation, recreational drug use or alcohol consumption. Examination showed a body mass index of $18 \mathrm{~kg} / \mathrm{m}^{2}$ without oral thrush or lymphadenopathy. A large solid fungating dark mass of $26.0 \times 20.0 \times 18.0 \mathrm{~cm}$ in size, raised from the right ankle and extended beyond the skin openly. The severely painful tumour contained necrotic soft tissue alternating with haemorrhagic areas (figures 1 and 2). The mass effect on the right lower limb impaired ambulation. The rest of physical examination was normal.

The patient showed suppressed viral loads with good CD4+ T cell counts (table 1). She also received highly active antiretroviral therapy (HAART) (table 2). Extensive investigations for other diseases were negative (table 1). MRI scan of the right ankle showed an irregularly shaped, infiltrating mass, measuring $1.0 \times 3.8 \times 3.1 \mathrm{~cm}^{3}$, located at the medial aspect of the right ankle, and extending into plantar region of the foot along the posterior tibial artery and nerve. This mass demonstrated low T1 signal, mildly high T2 signal and heterogeneous enhancement with intravenously administered Gadolinium. The tendons of foot appeared separate from the lesion. There was no osseous or articular involvement. The bones showed normal

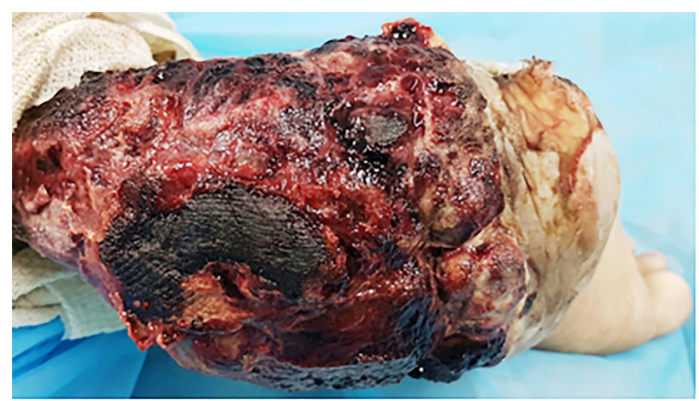

Figure 1 Posterior view image showing a large solid fungating dark mass of $26.0 \times 20.0 \times 18.0 \mathrm{~cm}$ in size, arising from the right ankle and extended beyond the skin openly. The mass contains necrotic tissue alternated with soft tissue bleeding areas.

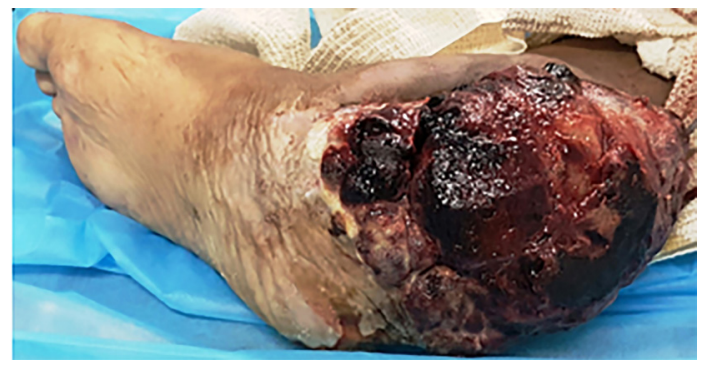

Figure 2 Lateral view image showing the tumour extension beyond the right ankle including the heel and the skin and soft tissue surrounding the heel.

MRI signal (figures 3-5). CT scan of the chest revealed multiple soft tissue density bilateral lung nodules, that measured up to $1.0 \mathrm{~cm}$ in diameter, suggestive of pulmonary metastasis. Tumour biopsy with histopathology using routine $H \& E$ staining and immunohistochemistry supported the diagnosis of synovial sarcoma (figures 6-8). Diagnosed as primary right ankle synovial sarcoma stage IV with metastases to the

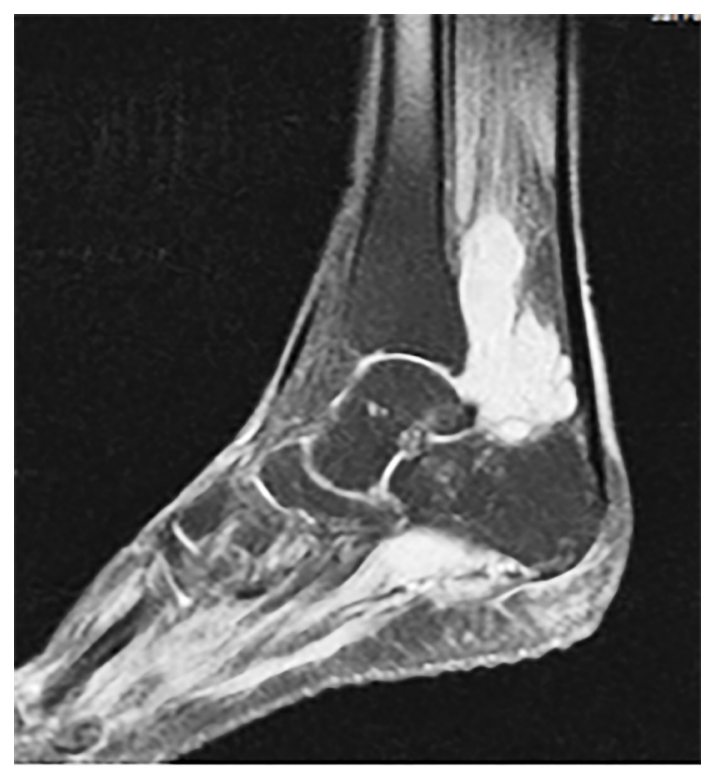

Figure 3 MRI scan of right foot and ankle showed a $1.0 \times 3.8 \times 3.1 \mathrm{~cm}^{3}$ irregularly shaped lesion noted at the medial aspect of the right ankle and extending into plantar aspect of the foot, along the posterior tibial artery and nerve. The mass demonstrated high $\mathrm{T} 2$ signal on this sagittal fat saturation view. 
Images in...

\begin{tabular}{|c|c|c|}
\hline Blood test & Result & $\begin{array}{l}\text { Reference } \\
\text { range }\end{array}$ \\
\hline White cell count & $8.7 \times 10^{9} / \mathrm{L}$ & $4.5-11.0 \times 10^{9} / \mathrm{L}$ \\
\hline Haemoglobin & $77 \mathrm{~g} / \mathrm{L}$ & $117-155 \mathrm{~g} / \mathrm{L}$ \\
\hline Mean corpuscular volume & $82.4 \mathrm{fL} / \mathrm{red}$ cell & $80-96 \mathrm{fL} / \mathrm{red}$ cell \\
\hline Platelets count & $668 \times 10^{9} / \mathrm{L}$ & $156-373 \times 10^{9} / \mathrm{L}$ \\
\hline $\begin{array}{l}\text { Venereal disease research } \\
\text { laboratory Test }\end{array}$ & Non-reactive & Non-reactive or reactive \\
\hline $\begin{array}{l}\text { Fluorescent Treponema } \\
\text { pallidum antibody } \\
\text { absorption }\end{array}$ & Negative & Positive or negative \\
\hline ELISA for HIV & Reactive & Non-reactive or reactive \\
\hline HIV viral load on admission & Not detected & - \\
\hline $\begin{array}{l}\text { HIV viral load } 2 \text { months from } \\
\text { admission }\end{array}$ & Not detected & - \\
\hline $\begin{array}{l}\text { CD4+ Tcell count on } \\
\text { admission }\end{array}$ & 455 cells/ $/ \mathrm{L}$ & 410-1590 cells/ $\mu \mathrm{L}$ \\
\hline $\begin{array}{l}\text { CD4+ T cell count } 2 \text { months } \\
\text { from admission }\end{array}$ & 650 cells/ $/ \mathrm{L}$ & $410-1590$ cells $/ \mu \mathrm{L}$ \\
\hline $\begin{array}{l}\text { Toxoplasma gondi lgG } \\
\text { antibodies }\end{array}$ & 0.43 & Negative: less than 0.55 \\
\hline $\begin{array}{l}\text { Toxoplasma gondi lgM } \\
\text { antibodies }\end{array}$ & 0.28 & Negative: less than 0.55 \\
\hline $\begin{array}{l}\text { Herpes virus } 1 \mathrm{lgG} \\
\text { antibodies }\end{array}$ & Negative & $\begin{array}{l}\text { Index negative: Less } \\
\text { than } 0.9\end{array}$ \\
\hline $\begin{array}{l}\text { Herpes virus } 1 \text { lgM } \\
\text { antibodies }\end{array}$ & Negative & $\begin{array}{l}\text { Index negative: Less } \\
\text { than } 0.9\end{array}$ \\
\hline $\begin{array}{l}\text { Herpes virus } 2 \text { lgG } \\
\text { antibodies }\end{array}$ & Negative & $\begin{array}{l}\text { Index negative: Less } \\
\text { than } 0.9\end{array}$ \\
\hline $\begin{array}{l}\text { Herpes virus } 2 \lg M \\
\text { antibodies }\end{array}$ & Negative & $\begin{array}{l}\text { Index negative: Less } \\
\text { than } 0.9\end{array}$ \\
\hline $\begin{array}{l}\text { Cytomegalovirus (CMV) IgG } \\
\text { antibodies }\end{array}$ & $0.700 \mathrm{UA} / \mathrm{mL}$ & $\begin{array}{l}\text { Negative: Less than } \\
1.5 \mathrm{UA} / \mathrm{mL}\end{array}$ \\
\hline CMV IgM antibodies & $0.578 \mathrm{UA} / \mathrm{mL}$ & $\begin{array}{l}\text { Negative: Less than } \\
1.1 \mathrm{UA} / \mathrm{mL}\end{array}$ \\
\hline $\begin{array}{l}\text { Epstein-Barr virus (EBV) IgG } \\
\text { antibodies }\end{array}$ & Negative & Negative: Less than 0.8 \\
\hline EBV IgM antibodies & Negative & Negative: Less than 0.8 \\
\hline Hepatitis BS AG & Negative & Positive or negative \\
\hline Hepatitis C IgG antibodies & Negative & Positive or negative \\
\hline Hepatitis C IgM antibodies & Negative & Positive or negative \\
\hline Pap smear & Normal & Normal or abnormal \\
\hline Genital examination & Normal & Normal or abnormal \\
\hline Mammogram both breast & Normal & Normal or abnormal \\
\hline Both breast ultrasound & Normal & Normal or abnormal \\
\hline $\begin{array}{l}\text { CT scan of head, abdomen } \\
\text { and pelvis }\end{array}$ & Normal & Normal or abnormal \\
\hline CT scan of the chest & Abnormal & Normal or abnormal \\
\hline MRI scan of the right ankle & Abnormal & Normal or abnormal \\
\hline
\end{tabular}

\begin{tabular}{|c|c|c|}
\hline Intravenous therapy & Dosage & $\begin{array}{l}\text { Period of } \\
\text { treatment }\end{array}$ \\
\hline Packed red blood cells & $\begin{array}{l}1 \text { unit three times a } \\
\text { week }\end{array}$ & 2 weeks \\
\hline Pethidine & $100 \mathrm{mg}$ twice daily & 1 week \\
\hline Dimenhydrinate & $50 \mathrm{mg}$ twice daily & 1 week \\
\hline Cefuroxime & $750 \mathrm{mg}$ three times daily & 1 week \\
\hline Subcutaneous drug & Dosage & $\begin{array}{l}\text { Period of } \\
\text { treatment }\end{array}$ \\
\hline Enoxaparin sodium & $40 \mathrm{mg}$ & 2 weeks \\
\hline Oral drug & Dosage & $\begin{array}{l}\text { Period of } \\
\text { treatment }\end{array}$ \\
\hline Efavirenz & $600 \mathrm{mg}$ daily & 3 years \\
\hline $\begin{array}{l}\text { Tenofovirdisoproxil/ } \\
\text { emtricitabine }\end{array}$ & $\begin{array}{l}245 / 200 \mathrm{mg} \text { per tablet } \\
1 \text { tablet daily }\end{array}$ & 3 years \\
\hline Pregabalin & $150 \mathrm{mg}$ daily & 6 months \\
\hline Cefuroxime axetil & $500 \mathrm{mg}$ twice daily & 15 days \\
\hline Tramadol hydrochloride/paracetamol & $\begin{array}{l}37.5 / 325 \mathrm{mg} \text { three times } \\
\text { daily }\end{array}$ & 15 days \\
\hline
\end{tabular}

lung in an adult living with HIV-AIDS, she underwent right above knee amputation, and received palliative therapy. One month later, significant clinical improvement led to discharge her home and subsequent periodic attendant to the oncology and HIV outpatient clinics. Six months later, patient developed metastatic pulmonary haemorrhage and died from this non-aid defining cancer complication despite control of the HIV-AIDS.

In 2015, there were 36.7 million people living with HIV-AIDS worldwide but the global coverage of HAART

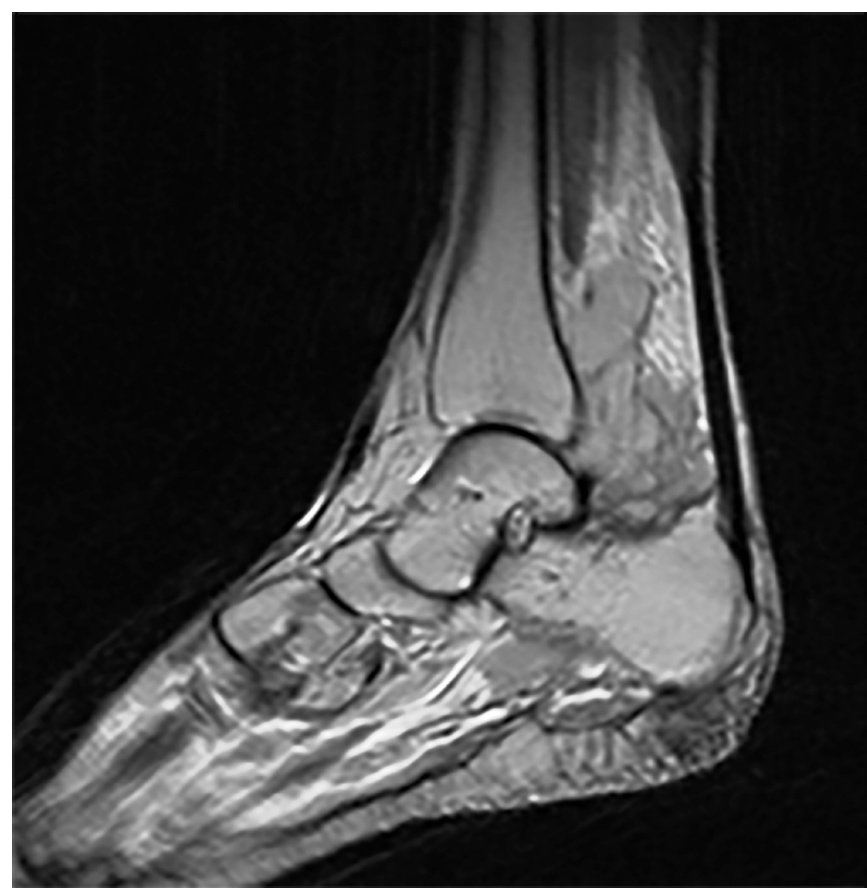

Figure 4 MRI scan of right foot and ankle shows low T1 signal on this T1-weighted sagittal view. reached only $46 \%$. Several long-term studies have indicated an increased risk for the development of a multitude of non-AIDS-defining cancers in HIV-AIDS patients such as non-Hodgkin's lymphomas, Kaposi sarcoma and cervical cancer. Very few reports, however, exist regarding the occurrence of non-AIDS-defining sarcomas in the extremities. ${ }^{1}$ The literature rarely mention the occurrence of bone and soft tissue tumours and also fail to describe the histological nature and site of these malignancies. Conventional synovial sarcoma among those patients with ages between 30 and 60 years is extremely rare. We have not found a previous publication regarding the occurrence of synovial sarcoma among

Reyes AJ, et al. BMJ Case Rep 2019;12:e228958. doi:10.1136/bcr-2018-228958 


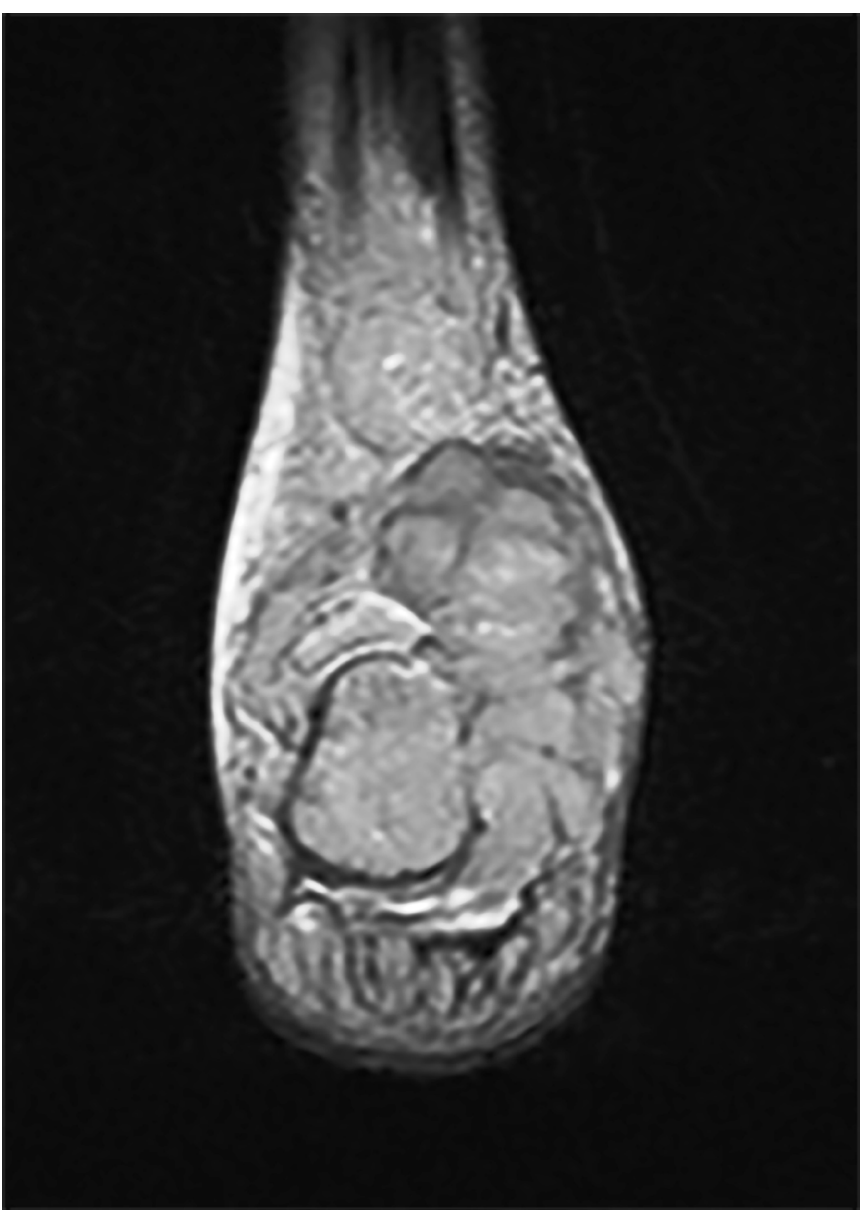

Figure 5 MRI scan of right foot and ankle with heterogeneous enhancement on IV gadolinium administration on this T1 weighted coronal view. It infiltrates into surrounding subcutaneous fat, without osseous or articular involvement. The tendons of foot appear separated from the lesion.

people living with HIV. ${ }^{1}$ The pathogenesis of many malignancies associated with HIV infection is not yet completely understood, but it may involve concomitant viral or other

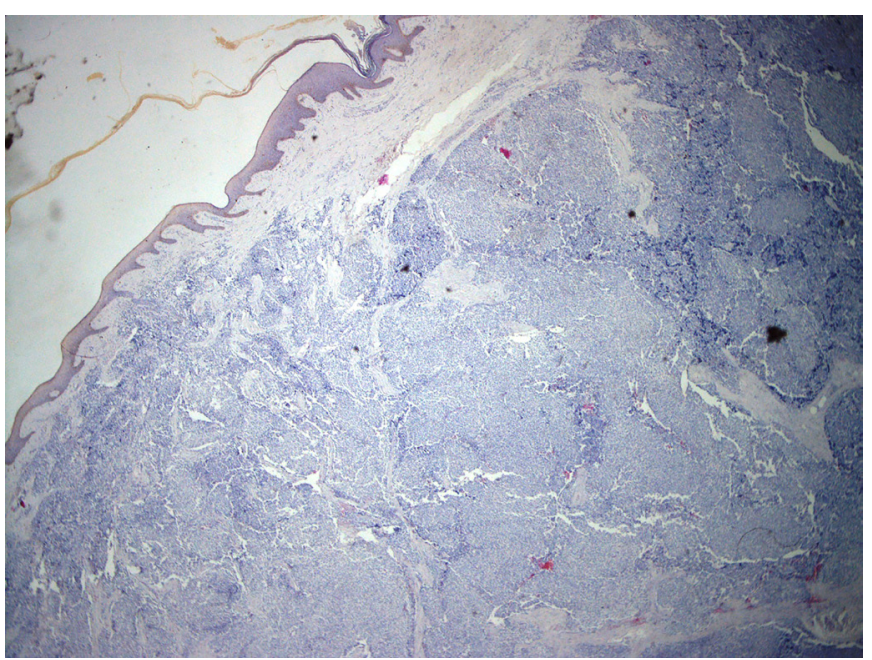

Figure 6 Tumour photomicrography: H\&E staining with skin undermined by a monophasic synovial sarcoma with fascicles of spindle shaped cells without epithelial component (20x magnification).

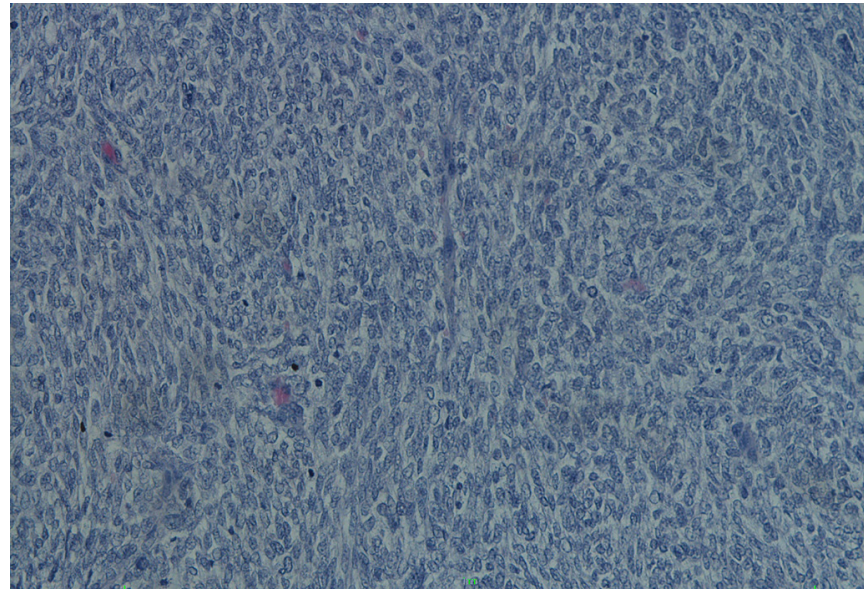

Figure 7 H\&E staining showing relatively ovoid uniform cells with occasional mitotic figures (200x magnification).

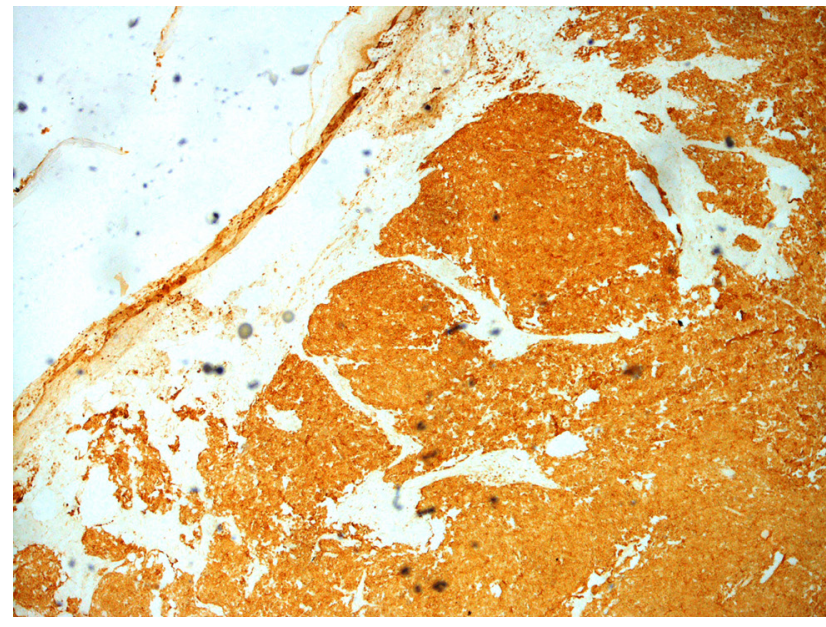

Figure 8 On immunohistochemistry, the tumour cells showed expression of $\mathrm{BCl}-2$ with strong staining and diffuse positive (4+) (40x magnification).

\section{Learning points}

- Synovial sarcoma of the ankle is an extremely rare and aggressive form of cancer but is perhaps unique as a concurrent malignancy among adults living with HIV-AIDS.

- Several comprehensive long-term follow-up studies rarely mention the occurrence of bone and soft tissue tumours among HIV-AIDS patients and also fail to describe the histological nature and site of these malignancies.

- The relationship of HIV-AIDS with osteosarcoma or sarcoma or synovial sarcoma remains uncertain

- The immunological basis of the development of malignancies in HIV-infected individuals is not yet completely understood. The pathogenesis of HIV inducing malignancy may involve direct virus carcinogenic actions or indirectly through immunosuppression.

- A greater index of suspicion is required in HIV patients presenting with unexplained bone and joint pain or swelling. Appropriate radiological investigation and timely referral to a specialised orthopaedic and oncology unit are recommended. 
microbial infections with direct carcinogenic actions or indirectly through immunosuppression. ${ }^{23}$

Contributors Conception and design, acquisition of data or analysis and interpretation of data was performed by AJR. Drafting the article or revising it critically for important intellectual content was done by AJR, WG, KR and FR. Final approval of the version published was done by all authors. All authors agree to be accountable for the article and to ensure that all questions regarding the accuracy or integrity of the article are investigated and resolved.

Funding The authors have not declared a specific grant for this research from any funding agency in the public, commercial or not-for-profit sectors.

Competing interests None declared.
Patient consent for publication Obtained.

Provenance and peer review Not commissioned; externally peer reviewed.

\section{REFERENCES}

1 Marais LC, Ferreira N. Osteosarcoma in Adult Patients Living with HIVIAIDS. ISRN Oncol 2013:2013:1-6.

2 World Health Organization. WHO case definitions of HIV for surveillance and revised clinical staging and immunological classification of HIV-related disease in adults and children. $2007 \mathrm{http}: / / w w w . w h o . i n t / h i v /$ pub/guidelines/ HIVstaging150307.pdf.

3 Butel JS. Viral carcinogenesis: revelation of molecular mechanisms and etiology of human disease. Carcinogenesis 2000;21:405-26.

Copyright 2019 BMJ Publishing Group. All rights reserved. For permission to reuse any of this content visit https://www.bmj.com/company/products-services/rights-and-licensing/permissions/

BMJ Case Report Fellows may re-use this article for personal use and teaching without any further permission.

Become a Fellow of BMJ Case Reports today and you can:

- Submit as many cases as you like

- Enjoy fast sympathetic peer review and rapid publication of accepted articles

- Access all the published articles

Re-use any of the published material for personal use and teaching without further permission

For information on Institutional Fellowships contact consortiasales@bmjgroup.com

Visit casereports.bmj.com for more articles like this and to become a Fellow 